\title{
Vietnam-China Trade Relations and the Effects of the US-China Trade War
}

\author{
Dr. Nguyen Quang Hiep \\ The University of Finance and Business Administration, Viet Nam \\ E-mail:nqhsta@gmail.com
}

Received: August 3, 2019 Accepted: August 23, 2019 Published: September 12, 2019

doi:10.5296/ber.v9i4.15201

URL: https://doi.org/10.5296/ber.v9i4.15201

\begin{abstract}
By calculating the trade indexes (TII, RCA and IIT), mainly in the period 2001-2017, the article analyzes current situation of the dependent relationship and ability to complement each other on trade between Vietnam and China. The results show that Vietnam and China are increasingly becoming important trade partners of each other; Vietnam and China have a particular advantage in the export structure of its exports, showing the trade relations between the two countries are complementary to each other; and the level of intra-industry trade between Vietnam and China is quite high. The US - China trade war broke out will cause the reversal of the global trade environment. However, in short term, the trade context of the Vietnam - China less affected by this tension. But in the long term, the sanctions are expanded to different sectors will can have unpredictable effects.
\end{abstract}

Keywords: Trade war, Comparative advantage, Intra-industry trade, Trade intensity index, Trade relations

\section{Introduction}

Since the normalization of relations in 1991, the friendship between Vietnam and China has grown rapidly and deeply in all fields. In particular, the economic and trade relations between Vietnam and China have been restored and developed rapidly. China has become one of the largest trading partners of Vietnam since the early 2000s. The benefits that bilateral trade brings to the two countries are easy to see.

Over the past decade, bilateral trade between Vietnam and China has increased almost thirty times, from about 3 billion USD in the year 2000 up close 88 billion USD in 2017 (According to the IMF figures). At the same time, China was consistently one of the largest trading partners of Vietnam. In terms of trade balance, Vietnam has always been a net importer from China. However, Vietnam's bilateral trade balance with China has improved over the last two 
years.

However, trade relations between Vietnam and China may be affected by the trade war between the US and China officially began in July 2018. The widespread retaliation of two major trading partners could be a bleak future for weaker countries. If these tensions are not resolved, the production chain can be adjusted to adapt to the new barrier. This will cause many countries to lose benefits even if they are not listed on the list of countries subject to sanctions imposed by the US and China, of course, Vietnam is no exception to that list.

This article will analyze the situation of dependency relationships and the ability to complement each other on trade between Vietnam and China. Besides that, give some analysis on the impact of US-China trade war on trade relations between Vietnam and China in the coming time.

\section{Research Methodology and Sources of Data}

To assess the current situation and prospects in trade relations between Vietnam and China, besides statistical synthesis methods, we mainly use the following indicators:

\subsection{The Trade Intensity Index (TII)}

The Trade Intensity Index used to assess the level of trade relations between two countries, specifically in this research is between Vietnam and China. The TII index also indicates the change in trade relations between two countries. According to the Asian Development Bank (ADB), this index is calculated according to the formula:

$$
\mathrm{TII}_{\mathrm{ij}}=\frac{\mathrm{T}_{\mathrm{ij}} / \mathrm{T}_{\mathrm{i}}}{\mathrm{T}_{\mathrm{j}} / \mathrm{T}_{\mathrm{w}}}
$$

Where: $\mathrm{TII}_{\mathrm{ij}}$ is the measure of the concentration of trade between country $\mathrm{i}$ and country $\mathrm{j}$; $\mathrm{T}_{\mathrm{ij}}$ is the trade value between the two countries; $T_{i}$ is the total trade value of country $i$; $T_{j}$ is the total trade value of country $\mathrm{j} ; \mathrm{T}_{\mathrm{w}}$ is the total trade turnover of the world. Thus, in formula (1), the numerator reflects the trade proportion of country $\mathrm{j}$ with country $\mathrm{i}$, the denominator reflects the trade proportion of country $\mathrm{j}$ with the world. Therefore, if $\mathrm{TII}_{\mathrm{ij}}>1$ means that country $i$ is an important trading partner for country $j$ rather than the world and vice versa.

\subsection{The Revealed Comparative Advantage (RCA)}

Balassa (1965) gave the formula for determining the comparative advantage of RCA. Formulas are used quite commonly in determining the comparative advantage of each particular commodity in a given period of time. This formula is one of the tools used to build a database on comparative advantage of members of the World Trade Organization.

$$
\operatorname{RCA}_{i j}=\frac{X_{i j} / X_{j}}{X_{i w} / X_{w}}
$$

Where: $\mathrm{RCA}_{\mathrm{ij}}$ is the comparative advantage index of commodity $\mathrm{i}$ of country $\mathrm{j}$ in a given 
period. $X_{i j}$ is the export turnover of commodity $i$ of country $j$ in the corresponding period, $X_{j}$ is the total export turnover of country $\mathrm{j}, \mathrm{X}_{\mathrm{iw}}$ is the export value of commodity $\mathrm{i}$ of the world, $X_{\mathrm{w}}$ is the total export turnover of the world. If RCA $>1$, that country is considered to have a comparative advantage in that good (or industry). If RCA $<1$, that country is considered to be disadvantageous in that good (or industry).

\subsection{Measure the Level of Intra-Industry Trade (IIT)}

Intra-industry trade is the purchase and sale of goods in the same industry. Increasing levels of intra-industry trade will help countries to increase economies of scale, reduce production costs, and bring more options and benefits to consumers. (Nguyen Van Tuan \& Tran Hoe, 2008, pp. 99-100).

The most used method of measuring intra-industry trade is the Grubel \& Lloyd index (1975). This indicator is considered to be the most appropriate method of assessing the structure of trade at a given time. This index is calculated by the following formula:

$$
\operatorname{IIT}_{\mathrm{ijk}}=1-\frac{\left|\mathrm{X}_{\mathrm{ijk}}-\mathrm{M}_{\mathrm{ijk}}\right|}{\mathrm{X}_{\mathrm{ijk}}+\mathrm{M}_{\mathrm{ijk}}}
$$

Where: IIT $_{\mathrm{ijk}}$ is the index of intra-industry trade of commodity $\mathrm{i}$ between two countries $\mathrm{j}$ and $\mathrm{k}, \mathrm{X}_{\mathrm{ijk}}$ is the exports value of commodity $\mathrm{i}$ of country $\mathrm{j}$ to country $\mathrm{k}$, and $\mathrm{M}_{\mathrm{ijk}}$ is the imports value of commodity $\mathrm{i}$ of country $\mathrm{j}$ from country $\mathrm{k}$. The IIT has a value of 0 to 1 , IIT $=0$ represents no intra-industry trade for commodity $i$ between country $j$ and country $k$, it means only exports or imports; IIT $=1$, it means exports equal to imports, represents trade between country $\mathrm{j}$ and country $\mathrm{k}$ is purely intra-industry trade for commodity $\mathrm{i}$.

The level of intra-industry trade is often high for processed goods, for countries with high levels of trade, countries with similar income levels, and countries with trade balances. The equilibrium with trade partners, and countries with large trade openings ... (Van Marrewijk, 2008; Vo Thy Trang, 2014; Nguyen Quang Hiep, 2016).

\subsection{Data Source}

Data in the paper were collected mainly from Direction Of Trade Statistics (DOTS) of the International Monetary Fund (IMF), and TRADE MAP in the period of 2001 - 2017.

\section{Research Results}

\subsection{Overview of Vietnam - China Trade Relations}




\section{Macrothink}

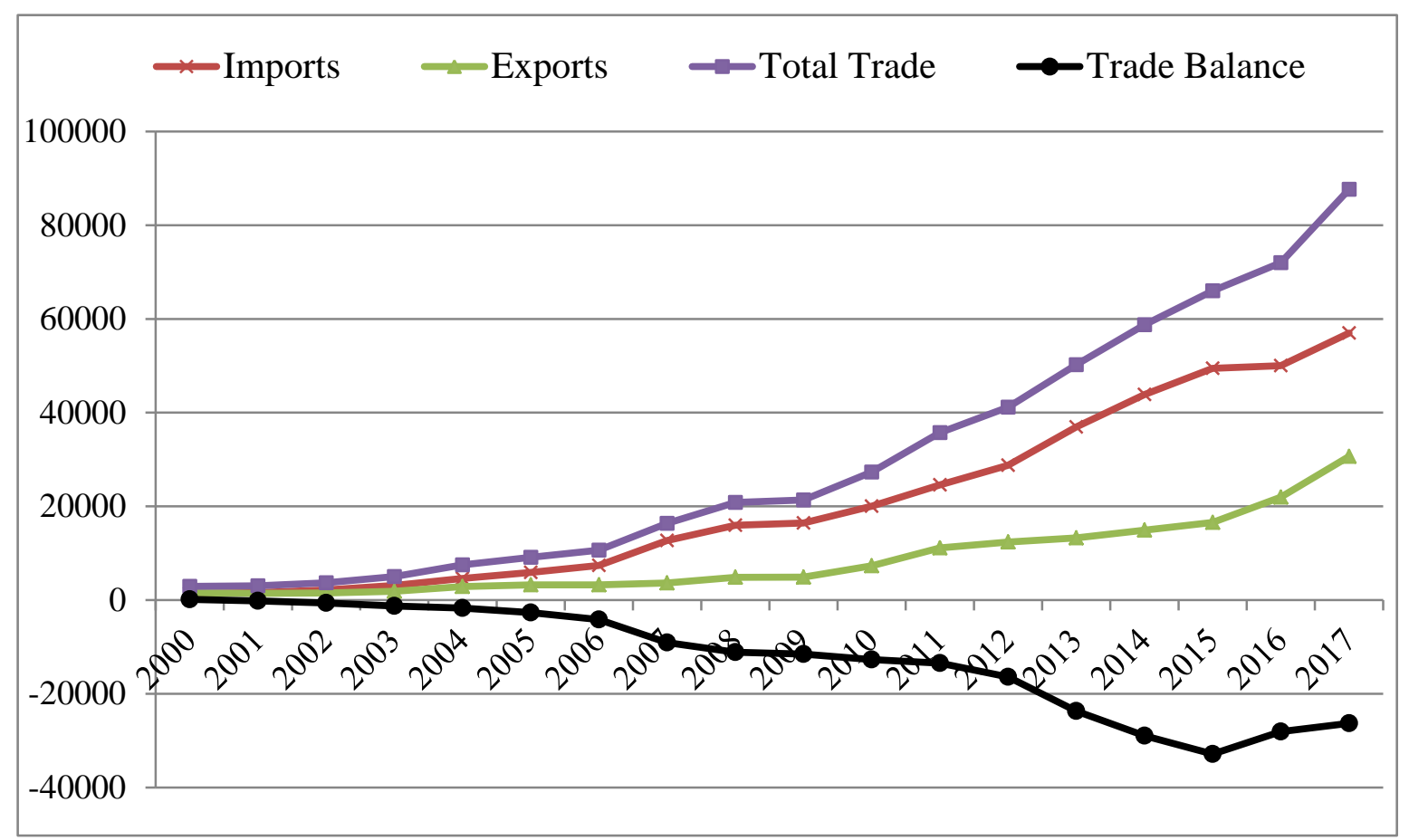

Figure 1. Vietnam's import-export turnover and trade balance for the Chinese market (million USD)

Source: The author calculated according to the data of IMF

Vietnam and China are two neighboring countries sharing the border, quite similar in terms of political, economic and cultural institutions. These characteristics have created great advantages for trade relations between the two countries. Accordingly, the value of two-way trade Vietnam - China has grown rapidly and continuously over the years. Over the past decade, bilateral trade between Vietnam and China has increased almost thirty times, from about 3 billion USD in the year 2000 upclose 88 billion USD in 2017 (According to the IMF figures). At the same time, China was consistently one of the largest trading partners of Vietnam, two-way trade between Vietnam and China on total trade flows of Vietnam in the years 2000, 2010 and 2017 were 9.8\%, 17.8\% and 20.4\% respectively. In 2017, China imported about $14.6 \%$ of the total export value of Vietnam, while Vietnam's imports from China have increased by about 40.7 times since 2000, from 1.4 billion USD to 57 billion USD, accounting for about $22 \%$ total import value of Vietnam. In terms of trade balance, the trade deficit of Vietnam from China has decreased in the last 2 years, but still in the trend of increasing. The trade deficit of Vietnam with China was 0.19 billion USD in 2001, 12.7 billion USD in 2010, 32.9 billion USD in 2015 and 26.3 billion in 2017. 
Table 1. Proportion of import and export commodities mainly between Vietnam and China $(\%)$

\begin{tabular}{|c|c|c|c|c|c|c|c|c|c|c|c|}
\hline \multirow[t]{2}{*}{ HS code ${ }^{1}$} & \multicolumn{5}{|c|}{ Vietnam imports from China } & \multirow[t]{2}{*}{ HS code } & \multicolumn{5}{|c|}{ Vietnam exports to China } \\
\hline & 2001 & 2005 & 2010 & 2015 & 2017 & & 2001 & 2005 & 2010 & 2015 & 2017 \\
\hline 27 & 13.3 & 16.4 & 8.0 & 2.5 & 1.7 & 07 & 1,3 & 2.0 & 3.0 & 1.3 & 0.5 \\
\hline 31 & 4.6 & 4.2 & 2.0 & 1.0 & 0.6 & 08 & 4,9 & 2.3 & 4,6 & 3.1 & 1.4 \\
\hline 52 & 1.2 & 3.7 & 5.1 & 3.0 & 2.3 & 26 & 1.7 & 4.8 & 4.5 & 0.5 & 0.6 \\
\hline 55 & 1.3 & 2.5 & 1.8 & 4.2 & 2.8 & 27 & 73.0 & 65.2 & 25.5 & 3.3 & 2.1 \\
\hline 60 & 0.4 & 2.4 & 3.2 & 3.5 & 4,2 & 40 & 5.3 & 6.7 & 7.5 & 2.6 & 3.0 \\
\hline 61 & 0.5 & 0,8 & 3.4 & 3.7 & 1.5 & 44 & 0.6 & 2.8 & 5.8 & 2.9 & 2.0 \\
\hline 72 & 6.6 & 13.5 & 7.1 & 6.3 & 6.0 & 52 & 0.3 & 0.3 & 4,8 & 4.9 & 4.2 \\
\hline 84 & 14.5 & 12.4 & 14.7 & 10.3 & 10.4 & 64 & 0.5 & 1.7 & 3.1 & 3.3 & 3,0 \\
\hline 85 & 3.0 & 6.6 & 15.6 & 19.0 & 26.8 & 84 & 0.9 & 2.1 & 9.2 & 3.7 & 2.7 \\
\hline 87 & 26.6 & 3.6 & 2.7 & 4.0 & 2.2 & 85 & 1.1 & 4.0 & 16.7 & 38.6 & 44.6 \\
\hline
\end{tabular}

Source: The author calculated according to the data of TRADE MAP

Regarding the structure of export and import goods, Table 1 shows that in the structure of goods of Vietnam exports to China, the major product groups are: Electrical machinery and equipment and parts thereof, sound recorders and reproducers, television... (HS85); Mineral fuels, mineral oils and products of their distillation, bituminous substances, mineral... (HS27); Wood and articles of wood, wood charcoal (HS44); Edible fruit and nuts, peel of citrus fruit or melons (HS08)... Vietnam imports from China mainly product groups: Electrical machinery and equipment and parts thereof, sound recorders and reproducers, television... (HS85); Machinery, mechanical appliances, nuclear reactors, boilers, parts thereof (HS84); Mineral fuels, mineral oils and products of their distillation, bituminous substances, mineral... (HS27); Iron and steel (HS72); Vehicles other than railway or tramway components, parts and accessories thereof (HS87); Man-made staple fibres (HS55).

\subsection{Trade Intensity Index}

The trade intensity index between Vietnam and China and some countries of ASEAN+3 is presented in Table 2. The results show that the trade intensity index between Vietnam and China tends to increase in recent years after a period of decline in 2007-2011, and always worth more than 1 . This reflects that Vietnam and China are becoming increasingly important trading partners of each other. However, compared to some ASEAN+3 partners, the index reflects the level of trade intensity between Vietnam and China is low. This is understandable because China has a very large international trade size, so the proportion of the trade between the two countries relative to China's total trade volume is very modest. Average in the period of 2010-2017, the total trade value of China has a size of about 3,833.4 billion USD, while trade between Vietnam and China in the same period only reached an average of 72.7 billion USD, accounting for about $1.9 \%$ of China's total trade turnover. 
Table 2. TII index between Vietnam and China, and some countries in the region

\begin{tabular}{|c|c|c|c|c|c|c|}
\hline Year & China & Thailand & Japan & Korea & Laos & Malaysia \\
\hline 2000 & 2.74 & 2.75 & 2.47 & 4.23 & 90.48 & 1.90 \\
\hline 2001 & 2.26 & 2.36 & 2.35 & 3.62 & 103.29 & 1.72 \\
\hline 2002 & 2.30 & 3.05 & 2.37 & 3.29 & 21.85 & 1.59 \\
\hline 2003 & 2.03 & 4.42 & 2.44 & 3.62 & 104.28 & 2.06 \\
\hline 2004 & 1.80 & 3.63 & 2.44 & 3.19 & 139.93 & 2.08 \\
\hline 2005 & 2.24 & 3.84 & 2.31 & 2.60 & 46.60 & 2.22 \\
\hline 2006 & 2.20 & 3.53 & 2.33 & 2.90 & 53.39 & 1.96 \\
\hline 2007 & 1.88 & 3.18 & 2.21 & 3.08 & 45.69 & 2.05 \\
\hline 2008 & 1.82 & 3.44 & 2.24 & 2.76 & 34.36 & 2.13 \\
\hline 2009 & 1.85 & 3.85 & 2.19 & 2.61 & 32.62 & 2.37 \\
\hline 2010 & 1.76 & 4.33 & 2.24 & 2.31 & 28.77 & 2.62 \\
\hline 2011 & 1.63 & 4.41 & 2.23 & 2.20 & 28.57 & 3.14 \\
\hline 2012 & 1.76 & 4.22 & 2.23 & 2.48 & 25.98 & 3.26 \\
\hline 2013 & 1.73 & 4.10 & 2.49 & 2.61 & 24.44 & 3.04 \\
\hline 2014 & 1.88 & 4.17 & 2.35 & 2.73 & 20.23 & 3.09 \\
\hline 2015 & 2.00 & 3.79 & 2.21 & 2.88 & 17.95 & 3.35 \\
\hline 2016 & 2.02 & 3.67 & 2.31 & 3.16 & 18.32 & 3.17 \\
\hline 2017 & 2.13 & 3.22 & 2.50 & 3.31 & 15.45 & 3.47 \\
\hline
\end{tabular}

Source: The author calculated according to the data of IMF

\subsection{Comparative Advantages of Vietnam and China}

The RCA is widely used in determining the comparative advantage of countries for a particular commodity in a given period of time. RCA index of Vietnam and China in the period 2001-2017 is relatively clear. Table 3 only shows the products of Vietnam and China have the highest comparative advantage by 2017 .

Table 3 shows the group of commodities such as: Footwear, gaiters and the like, parts of such articles (HS64); Manufactures of straw, of esparto or of other plaiting materials, basketware and wickerwork (HS46); Coffee, tea, maté and spices (HS09); Articles of apparel and clothing accessories, not knitted or crocheted (HS62); Articles of apparel and clothing accessories, knitted or crocheted (HS61); Fish and crustaceans, molluscs and other aquatic invertebrates (HSO3 )... are the groups that Vietnam has high comparative advantages over the years.

Meanwhile, China has a high comparative advantage for groups such as: Umbrellas, sun umbrellas, walking sticks, seat-sticks, whips, riding-crops and parts thereof (HS66 ); Prepared feathers and down and articles made of feathers or of down, artificial flowers, articles ... (HS67); Manufactures of straw, of esparto or of other plaiting materials, basketware and wickerwork (HS46); Silk (HS50 ); Headgear and parts thereof (HS65 ); Toys, games and sports requisites, parts and accessories thereof (HS95); ... 
Table 3. Group items that Vietnam and China has the highest comparative advantage under the RCA index

\begin{tabular}{|c|c|c|c|c|c|c|c|c|c|c|c|}
\hline \multirow[t]{2}{*}{ HS code } & \multicolumn{5}{|c|}{ Vietnam } & \multirow[t]{2}{*}{ HS code } & \multicolumn{5}{|c|}{ China } \\
\hline & 2001 & 2005 & 2010 & 2015 & 2017 & & 2001 & 2005 & 2010 & 2015 & 2017 \\
\hline 64 & 14.1 & 14.8 & 11.3 & 9.5 & 9.8 & 66 & 10.4 & 8.0 & 7.2 & 5.8 & 5.9 \\
\hline 46 & 27.6 & 25.2 & 14.3 & 8.5 & 7.0 & 67 & 8.8 & 6.2 & 6.2 & 5.6 & 5.7 \\
\hline 09 & 19.1 & 16.9 & 14.3 & 8.4 & 6.3 & 46 & 11.6 & 8.3 & 6.7 & 5.0 & 5.0 \\
\hline 62 & 6.0 & 6.2 & 6.5 & 5.3 & 4.2 & 50 & 8.5 & 5.6 & 4.8 & 3.9 & 4.2 \\
\hline 61 & 1.5 & 4.4 & 5.7 & 4.7 & 4.0 & 95 & 4.8 & 4.2 & 3.3 & 3.2 & 3.7 \\
\hline 42 & 3.3 & 3.3 & 3.5 & 3.7 & 3.5 & 60 & 2.1 & 2.5 & 3.1 & 3.2 & 3.7 \\
\hline 65 & 3.8 & 7.1 & 5.3 & 3.4 & 3.2 & 65 & 4.9 & 4.5 & 4.4 & 3.9 & 3.6 \\
\hline 52 & 0.4 & 0.3 & 2.4 & 3.1 & 3.2 & 63 & 4.5 & 4.2 & 3.9 & 3.2 & 3.2 \\
\hline 03 & 16.8 & 13.5 & 10.5 & 4.9 & 2.9 & 43 & 2.8 & 4.5 & 2.3 & 2.2 & 3.1 \\
\hline 16 & 1.8 & 3.9 & 5.1 & 3.9 & 2.8 & 54 & 1.3 & 2.1 & 2.3 & 2.5 & 3.0 \\
\hline
\end{tabular}

Source: The author calculated according to the data of TRADE MAP

Assess about the shift of the comparative advantage structure, table 4 shows that, in the period 2001-2010, Vietnam's comparative advantage is relatively positive. Comparative advantage structure has shifted from raw and pre-processing products into processed products. In the structure of processed products, the proportion of processed products with added value and high technology content has gradually increased. However, the comparative advantage structure of Vietnam is still largely based on agricultural products and low-end products such as textiles, footwear, wood and wood products..., since 2011 more new products have been added, such as higher processing phones, computers and components. For China, the total number of commodities with comparative advantage in 2001 was 46, then dropped to 44 in the 2010 and 2017; comparative advantage is mainly based on the mix processed products, machinery and means of transport, and the structure of comparative advantage still have quite a positive shift from the raw products into semi-processed and processed products.

Thus, it can be seen that Vietnam and China both have their own comparative advantage in the structure of their exports, showing that the trade relations between the two countries are complementary. Comparative advantages of the two countries are mostly labor-intensive and low value added goods. However, China has a higher proportion of manufactured goods in the comparative advantage structure than in Vietnam. 


\section{Macrothink}

Business and Economic Research

ISSN 2162-4860

Table 4. Comparative advantages of Vietnam and China

\begin{tabular}{|c|c|c|c|c|c|c|c|c|c|c|c|c|}
\hline \multirow{3}{*}{ Group of goods } & \multicolumn{6}{|l|}{ Vietnam } & \multicolumn{6}{|l|}{ China } \\
\hline & \multicolumn{2}{|l|}{2001} & \multicolumn{2}{|l|}{2010} & \multicolumn{2}{|l|}{2017} & \multicolumn{2}{|l|}{2001} & \multicolumn{2}{|l|}{2010} & \multicolumn{2}{|l|}{2017} \\
\hline & $\begin{array}{l}\text { Number of } \\
\text { item codes }\end{array}$ & $\begin{array}{l}\text { Structure } \\
(\%)\end{array}$ & $\begin{array}{l}\text { Number of } \\
\text { item codes }\end{array}$ & $\begin{array}{l}\text { Structure } \\
(\%)\end{array}$ & $\begin{array}{l}\text { Number of } \\
\text { item codes }\end{array}$ & $\begin{array}{l}\text { Structure } \\
(\%)\end{array}$ & $\begin{array}{l}\text { Number of } \\
\text { item codes }\end{array}$ & $\begin{array}{l}\text { Structure } \\
(\%)\end{array}$ & $\begin{array}{l}\text { Number of } \\
\text { item codes }\end{array}$ & $\begin{array}{l}\text { Structure } \\
(\%)\end{array}$ & $\begin{array}{l}\text { Number of } \\
\text { item codes }\end{array}$ & $\begin{array}{l}\text { Structure } \\
(\%)\end{array}$ \\
\hline $\begin{array}{l}\text { Live animals and animals; animal fat/ } \\
\text { vegetable oil; Processed food and } \\
\text { beverages (From HS01-HS24) }\end{array}$ & 16 & 47.1 & 10 & 28.6 & 7 & 25.0 & 8 & 17.4 & 6 & 13.6 & 5 & 11.4 \\
\hline Minerals (HS25-HS27) & 1 & 2.9 & 1 & 2.9 & 1 & 3.6 & 1 & 2.2 & 0 & 0.0 & 0 & 0.0 \\
\hline Chemicals (From HS28-HS40) & 2 & 5.9 & 2 & 5.7 & 1 & 3.6 & 2 & 4.3 & first & 2.3 & 3 & 6.8 \\
\hline $\begin{array}{ll}\text { Mixed processed } & \text { products } \\
(\text { HS41-HS83) } & \\
\end{array}$ & 13 & 38.2 & 20 & 57.1 & 15 & 53.6 & 28 & 60.9 & 28 & 63.6 & 28 & 63.6 \\
\hline $\begin{array}{l}\text { Machinery, means of transport } \\
\text { (HS84-HS93) }\end{array}$ & 0 & 0.0 & 0 & 0.0 & 1 & 3.6 & 4 & 8.7 & 6 & 13.6 & 5 & 11.4 \\
\hline Others (From HS94-HS99) & 2 & 5.9 & 2 & 5.7 & 3 & 10.7 & 3 & 6.5 & 3 & 6.8 & 3 & 6.8 \\
\hline $\begin{array}{l}\text { Total number of goods have } \\
\text { comparative advantage }\end{array}$ & 34 & 100 & 35 & 100 & 28 & 100 & 46 & 100 & 44 & 100 & 44 & 100 \\
\hline
\end{tabular}

Source: The author calculated according to the data of TRADE MAP

\subsection{The Level of Intra-industry Trade between Vietnam and China}

Intra-industry trade is the simultaneous export and import of products in the same industry. Intra-industry trade creates more gains from international trade, economies of scale, and increased choice. By engaging in intra-industry trade, a country can reduce the number of products it produces at the same time and increase the diversity of its consumer goods in the domestic market.

The Intra-industry trade (IIT) between Vietnam and China are presented in Table 5, which only includes a number of commodity groups with high intra-industry trade index in 2017 (including 25 groups of goods have the highest intra-industry trade index). Some of the groups with high IIT index are: Raw hides and skins (other than furskins) and leather (HS41); Optical, photographic, cinematographic, measuring, checking, precision, medical or surgical ... (HS 90); Electrical machinery and equipment and parts thereof, sound recorders and reproducers, television... (HS85); Footwear, gaiters and the like, parts of such articles (HS64); Edible fruit and nuts, peel of citrus fruit or melons (HS08); Beverages, spirits and vinegar (HS22); Coffee, tea, maté and spices (HS09); Mineral fuels, mineral oils and products of their distillation, bituminous substances, mineral ... (HS27); Salt, sulphur, earths and stone, plastering materials, lime and cement (HS25);... Including The 13 ITT categories are larger than 0.8 , accounting for $47.2 \%$ of total trade between Vietnam and China. In general, the level of intra-industry trade between Vietnam and China is quite high, reflected in the proportion of the number of groups with high intra-industry trade in total trade 


\section{Macrothink}

Business and Economic Research

ISSN 2162-4860

turnover between the two countries. The proportion of the commodity groups of intra-industry trade index equal to or greater than 0.5 in 2017 accounts for about $51.6 \%$ of total trade between Vietnam and China.

Table 5. Group of items have high IIT

\begin{tabular}{|c|c|c|c|c|c|c|c|c|c|c|}
\hline \multirow[t]{2}{*}{ HS code } & \multicolumn{2}{|l|}{2001} & \multicolumn{2}{|l|}{2005} & \multicolumn{2}{|l|}{2010} & \multicolumn{2}{|l|}{2015} & \multicolumn{2}{|l|}{2017} \\
\hline & IIT & Proportion $^{2}(\%)$ & IIT & Proportion (\%) & IIT & Proportion $(\%)$ & IIT & Proportion $(\%)$ & IIT & Proportion (\%) \\
\hline 41 & 0.228 & 0.388 & 0.086 & 0.783 & 0.473 & 0.377 & 0.713 & 0.351 & 0.993 & 0.277 \\
\hline 90 & 0.043 & 0.310 & 0.228 & 0.472 & 0.280 & 1.257 & 0.313 & 2.583 & 0.960 & 3.202 \\
\hline 23 & 0.182 & 0.338 & 0.261 & 0.156 & 0.388 & 0.363 & 0.785 & 0.315 & 0.945 & 0.290 \\
\hline 27 & 0.489 & 34.782 & 0.716 & 31.607 & 0.981 & 12.062 & 0.745 & 2.759 & 0.936 & 1.864 \\
\hline 85 & 0.344 & 2.342 & 0.435 & 5.768 & 0.489 & 15.843 & 0.956 & 25.118 & 0.924 & 34.094 \\
\hline 15 & 0.003 & 0.677 & 0.136 & 0.048 & 0.850 & 0.074 & 0.683 & 0.021 & 0.924 & 0.016 \\
\hline 52 & 0.203 & 0.890 & 0.076 & 2.665 & 0.449 & 5.001 & 0.843 & 3.606 & 0.880 & 3.072 \\
\hline 06 & 0.683 & 0.006 & 0.000 & 0.003 & 0.602 & 0.009 & 0.318 & 0.011 & 0.870 & 0.008 \\
\hline 25 & 0.154 & 0.242 & 0.160 & 0.275 & 0.972 & 0.236 & 0.953 & 0.091 & 0.864 & 0.105 \\
\hline 21 & 0.038 & 0.104 & 0.102 & 0.052 & 0.219 & 0.086 & 0.996 & 0.186 & 0.852 & 0.273 \\
\hline 64 & 0.438 & 0.743 & 0.976 & 1.063 & 0.764 & 1.164 & 0.977 & 2.018 & 0.824 & 2.084 \\
\hline 42 & 0.896 & 0.061 & 0.834 & 0.117 & 0.487 & 0.227 & 0.861 & 0.320 & 0.815 & 0.490 \\
\hline 08 & 0.230 & 1.992 & 0.863 & 1.641 & 0.900 & 1.922 & 0.942 & 1.823 & 0.803 & 1.432 \\
\hline 43 & 0.000 & 0.008 & 0.005 & 0.095 & 0.008 & 0.088 & 0.592 & 0.296 & 0.746 & 0.181 \\
\hline 71 & 0.000 & 0.006 & 0.319 & 0.005 & 0.002 & 0.136 & 0.280 & 0.071 & 0.728 & 0.041 \\
\hline 09 & 0.812 & 0.456 & 0.370 & 0.114 & 0.457 & 0.167 & 0.992 & 0.175 & 0.724 & 0.358 \\
\hline 03 & 0.044 & 0.323 & 0.571 & 0.448 & 0.769 & 0.281 & 0.900 & 0.152 & 0.655 & 0.278 \\
\hline 78 & 0.017 & 0.038 & 0.000 & 0.030 & 0.122 & 0.109 & 0.075 & 0.056 & 0.654 & 0.015 \\
\hline 61 & 0.057 & 0.302 & 0.194 & 0.597 & 0.057 & 2.688 & 0.249 & 2.909 & 0.628 & 1.295 \\
\hline 19 & 0.414 & 0.038 & 0.234 & 0.061 & 0.631 & 0.019 & 0.771 & 0.029 & 0.627 & 0.032 \\
\hline 22 & 0.001 & 0.075 & 0.002 & 0.021 & 0.078 & 0.008 & 0.945 & 0.028 & 0.625 & 0.022 \\
\hline 28 & 0.012 & 2.024 & 0.003 & 1.532 & 0.014 & 0.807 & 0.671 & 0.602 & 0.607 & 0.571 \\
\hline 97 & 0.000 & 0.000 & 0.136 & 0.001 & 0.081 & 0.001 & 0.024 & 0.001 & 0.604 & 0.000 \\
\hline 20 & 0.635 & 0.031 & 0.177 & 0.042 & 0.325 & 0.061 & 0.258 & 0.174 & 0.579 & 0.153 \\
\hline 01 & 0.114 & 0.002 & 0.000 & 0.002 & 0.415 & 0.002 & 0.401 & 0.002 & 0.564 & 0.007 \\
\hline
\end{tabular}

Source: The author calculated according to the data of TRADE MAP 
3.5 Assess the Effects of the US -China Trade War on Trade Relations of the Two Countries

The US-China trade war started officially when the US imposed import tariffs of $25 \%$ on goods from China on June 07, 2018, of which $90 \%$ is in material goods production. Immediately, Beijing announced the imposition of similar taxes on 545 items imported from the US, including agricultural products, vehicles and seafood. The total value of imports of these commodities from the US to China annually is 34 billion USD (An Huy, 2018).

The widespread retaliation of two major trading partners could be a bleak future for weaker countries. With the overall growth of the world economy, the reversal of the global trading environment will have a direct impact on the economic growth of all nations. In 2017, according to the World Trade Organization (WTO), global trade growth is expected to reach $4.7 \%$, but by 2018 , this growth may be less predictable.

If these tensions are not resolved, the production chain can be adjusted to adapt to the new barrier. This will cause many countries to lose benefits even if they are not listed on the list of countries subject to sanctions imposed by the United States and China, of course, Vietnam is no exception to that list. However, in the short-term Vietnam is less affected by this tension because the sectors that the United States punished China are not the main export sectors that Vietnam exports to China. Vietnam is also at the bottom of the global production chain, so the US-China trade tension will hardly change the trade relations between China and Vietnam in the short term.

However, in the long run, the imposition of sanctions on other sectors will have unpredictable consequences. The trade war could spur the influx of Chinese goods into Vietnam after the devaluation of the Yuan and Chinese goods could not export to the United States as much as before. If China wants to maintain its capacity and growth, it must find new markets. One of the potential markets for this country may be Vietnam. In the opposite direction, China will also focus more on the domestic market, causing the demand for imports from countries, including Vietnam, is reduced. This is a big challenge for Vietnam when our export size is equivalent to $93 \%$ of GDP in 2017, of which China is Vietnam's third largest export market.

\section{Conclude}

The economic and trade relations between Vietnam and China have been restored and developed rapidly. China has become one of the biggest trading partners of Vietnam since the early 2000s. Through the analysis of current status and calculation of trade indicators (TII, RCA and IIT), the results show that:

First, Vietnam and China increasingly become important trade partners of each other. This is reflected in the trade intensity index between Vietnam and China tended to increase over the years.

Second, Vietnam and China have their own comparative advantage in the structure of their exports, showing that the trade relations between the two countries are complementary. Comparative advantages of the two countries are mostly labor-intensive and low value added goods. However, China has a higher proportion of manufactured goods in the comparative 
advantage structure than Vietnam.

Third, the level of intra-industry trade between Vietnam and China is quite high, reflecting the high proportion of intra-industry trade in total trade volume between the two countries. However, the proportion of processed products in the structure of exports from Vietnam to China is not high, the trade balance between the two countries is unbalanced...

The US-China trade war will trigger a reversal of the global trade environment. However, in short term, the trade context of the Vietnam - China less affected by this tension. But in the long term, the sanctions are expanded to different sectors will can have unpredictable effects.

\section{Endnotes}

1. HS code (Harmonized System) is a harmonized list of goods (Ministry of Finance, 2011).

2. Proportion in total trade between Vietnam and China

\section{References}

An Huy (2018). China imposed a tax on US goods, declared "the largest trade war in history". [Online] Available: http://vneconomy.vn/trung-quoc-ap-thue-len-hang-my-tuyen-bo-chien-tra nhong-mai-lan-nhich-su-20180706145340019.htm

Balassa, B. (1965). Trade Liberalization and Revealed Comparative Advantage. The Manchester School, 33(2). 99-123. https://doi.org/10.1111/j.1467-9957.1965.tb00050.x

Grubel, H. G., \& Lloyd, P. J. (1975). Intra-Industry Trade: The Theory and Measurement of International Trade in Differentiated Products. MacMillan. London.

Ministry of Finance (2011). The list of imported goods in Vietnam. issued together with Circular No. 156/2011/TT-BTC. November 14. 2011 of the Ministry of Finance.

Nguyen Quang Hiep (2016). 20 years of US-Vietnam relations: evaluation through trade indicators. Journal of Economics and Development, 231, 2-9.

Nguyen Van Tuan \& Tran Hoe (2008). International Trade - Part 1. National Economics University Publisher.

Van Marrewijk, Charles (2008). Intra-Industry Trade. World Economy. Princeton University Press. Department of Economics. Erasmus University Rotterdam. Holland.

Vo Thi Thy Trang (2014). Applying the gravity model in the measurement of intra-industry trade between Vietnam and some APEC member countries. Journal of Science \& Technology, 117(03). 167-176.

\section{Copyright Disclaimer}

Copyright for this article is retained by the author(s), with first publication rights granted to the journal.

This is an open-access article distributed under the terms and conditions of the Creative Commons Attribution license (http://creativecommons.org/licenses/by/3.0/). 